\title{
Serine Protease Hepsin
}

National Cancer Institute

\section{Source}

National Cancer Institute. Serine Protease Hepsin. NCI Thesaurus. Code C101720.

Serine protease hepsin (417 aa, $\sim 45 \mathrm{kDa}$ ) is encoded by the human HPN gene. This protein is involved in proteolysis. 